\title{
SLC3A1 wt Allele
}

National Cancer Institute

\section{Source}

National Cancer Institute. SLC3A1 wt Allele. NCI Thesaurus. Code C94689.

Human SLC3A1 wild-type allele is located in the vicinity of $2 \mathrm{p} 16.3$ and is approximately 46 $\mathrm{kb}$ in length. This allele, which encodes neutral and basic amino acid transport protein rBAT, plays a role in the regulation of amino acid transport. Mutation of the gene is associated with cystinuria type 1 and hypotonia-cystinuria syndrome. 